\title{
An Empirical Investigation of Internal and External Factors Associated with Audit Report Lag in Indonesia
}

\author{
Teti Rahmawati ${ }^{1}$, Enung Nurhayati ${ }^{2}$, Lia Dwi Martika ${ }^{3}$, Herma Wiharno ${ }^{4}$, Oktaviani \\ Rita Puspasari ${ }^{5}$
}

Fakultas Ekonomi, Universitas Kuningan, Indonesia

$\left\{\right.$ teti.rahmawati@uniku.ac.id ${ }^{1}$, enung.nurhayati@uniku.ac.id², lia.dwimartika@uniku.ac.id ${ }^{3}$,
herma.wiharno@uniku.ac.id ${ }^{4}$, oktaviani.ritapuspasari@uniku.ac.id $\left.{ }^{5}\right\}$

\begin{abstract}
The purpose of this study is to provide empirical evidence regarding the effect of profitability, leverage, liquidity, auditor opinion, and public accounting firm's (Kantor Akuntansi Publik/KAP) reputation on audit report lag. The independent variables in this study are profitability measured by using ROA, leverage measured by using DER, liquidity measured by using CR, auditor's opinion measured by using interval variables, where two of them are for companies that get unqualified opinion without exception, and the other one is for companies that get opinions other than unqualified opinion. Accounting firm reputation are measured by using interval variables, where two of them are for companies affiliated with The Big Four of public accounting firm (KAP) and the other one is for companies other than affiliated with The Big Four of public accounting firm (KAP). This study uses secondary data from annual financial reports listed on the Indonesia Stock Exchange. This study's population was 34 transportation sector companies listed on the Indonesia Stock Exchange for the period of 2014-2018. By using purposive technique sampling, obtained 26 company samples with 130 observations. The results show that simultaneously profitability, leverage, liquidity, auditor opinion, and public accounting firm's reputation significantly affect the timeliness of financial reporting. Meanwhile, partial testing shows that profitability, liquidity, leverage, auditor opinion, and accounting firm's reputation significantly affect audit report lag
\end{abstract}

Keywords: Profitability; Leverage; Liquidity; Auditor Opinion; Accounting Firm Reputation; Audit Report Lag

\section{Introduction}

The financial report is a structure that describes the financial condition and financial performance of an entity (IAI, 2017: 5). Financial statements are the output of the company's operational activities and will provide useful financial information for the users, namely for entities within the company and entities outside the company. The main indicator in producing financial reports that can provide relevant information is timeliness in its delivery, which is available when users of financial statements need it in making a decision. If there is a delay in the presentation of financial statements, the information generated in the financial statements will lose its relevance for users of financial information, especially for investors in making investment decisions (Putri, 2014). Companies in Indonesia, especially companies that have gone public, are required to prepare financial reports every year (Fadoli, 2014). Companies often experience a problem when they have to present financial reports in a timely manner, 
one of which is that the financial statements must be audited first by a public accountant before being submitted to the public so that they can be trusted by all users. The purpose of being audited is to provide an opinion on the fairness of the company's financial statements based on predetermined or generally accepted reporting standards.

This can be seen from the Public Accountant Professional Standards (Standar Profesional Akuntan Publik) which have been established by the Indonesian Institute of Certified Public Accountants (Institut Akuntan Publik Indonesia) in the third standard that audits must be carried out with full accuracy and thoroughness and the collection of sufficient evidence tools. Collecting evidence as a basis for the audit will affect the length of time completion of the audit report and the quality of the audit. If the audit process is in line with audit standards, the audit implementation will take longer (Putri, 2014). Another obstacle is the timeliness of auditors in completing their audit reports when companies publish their financial reports to the public and to the Capital Market Supervisory Agency (Badan Pengawas Pasar Modal).

The delay in information delivery has resulted in a decrease of investor confidence level. This can affect the selling price of shares in the capital market. In general, investors consider that late financial reporting is a bad sign for the company's health condition. Companies with poor health condition are more prone to mismanagement. The level of profit and the company's survival is disrupted, in the end it requires a high level of care and precision at the time of auditing. This causes the audit report lag, or some call it the audit delay, to increase.

Decree of the Chairman of the Capital Market Supervisory Agency (BAPEPAM) and Financial Institutions (Lembaga Keuangan) No: KEP-346 / BL / 2011 obligates every issuer and public company listed on the Indonesia Stock Exchange to submit an annual financial report and an accountant's report in order to audit the report of financial statements containing the audit opinion from the accountant to BAPEPAM and LK no later than 3 months (90 days) after the date of the annual financial statements. Based on information obtained from the site www.idx.co.id in 2019 there are still many companies that are late in submitting their financial reports. In 2019, it was recorded that 18 companies had not submitted audited financial reports. The length of time to complete the audit can be determined through the time span between the closing date of the company's books and the date of issuance of the audit report or auditor's opinion (audit report lag). Knechel and Payne in sBangun, et al. (2012) explain that the audit report lag is the time period between the end of the fiscal year and the date of the company's audit report.

Several factors that influence audit report lag have been widely studied by previous researchers. According to Catur Wulan Ningsih (2013: 4) internal and external factors that affect the audit report lag, namely company size, profitability, solvency (leverage), auditor quality, auditor opinion, complexity of company operations, and operating profit and loss. Meanwhile, according to Imam Fadoli (2014: 4), internal and external factors that affect the audit report lag are profitability, solvency (leverage), liquidity, company size, company age, type of industry, and auditor opinion. In addition, according to Ashton et al in Zulaikha (2019), the factors that affect the audit report lag that come from within the company are total revenue, type of industry, complexity of financial reports, complexity of electronic data, profit / loss, company age, extraordinary posts, the complexity of the company's operations and the size of the company.

Meanwhile, factors that come from outside the company that affect the audit report lag are audit opinion, auditor reputation, and auditor quality. Apart from these factors, one of the factors that influence the audit report lag is the convergence of IFRS (Kurnia, 2016). Heru (2013) says that the level of dependence of external users on audited financial reports has several indicators that make a financial report very reliable, including the size of the entity, the 
distribution of ownership, and the large amount of debt / liability of the entity. The objectives of this study are 1) To examine the influence of the company's internal factors (Profitability, Leverage, Liquidity) on the audit report lag; 2) To test the company's external factors (Auditor Opinion, Accounting Firm's Reputation) on the audit report lag

\section{Method}

According to Kasmir (2013: 113) the leverage ratio is a ratio used to measure the extent to which the company's assets are financed by debt. This ratio will be measured by using the debt to equity ratio, which shows the ability of assets to fund the company's debt. The results of research by Sumbawa and Dwiana (2016), Sastrawan and Latrini (2016), and Indriyani and Supriyati (2012) in their hypothesis testing show that the level of leverage has a positive effect on audit report lag (audit delay), because the high debt of a company is bad news, and affects the company's reputation in the eyes of the public, so that management tends to delay the delivery of its financial statements because the available time will be used to reduce the debt to equity ratio as low as possible, which will make the audit report lag even longer. If a large company or small company has a low debt to equity ratio of leverage level, it indicates that the company's obligation to pay off debt is also low so that the company no longer needs to suppress the debt to equity ratio and the submission of financial reports can be done on time, so the audit report lag time can be shortened.

\section{H1. Leverage has a negative effect on audit report lag}

Profitability is a ratio to assess the company's ability to seek profits (Kasmir, 2013: 196). The profitability factor is another factor that affects the audit report lag. The profitability of a company can be measured by the profitability ratio. The higher the profitability ratio, the greater the profit generated. According to Carslaw in the research of Letters and Latrini (2016), there are two reasons why companies that suffer losses tend to experience a longer audit report lag. First, when a loss occurs, the company wants to postpone bad news, so the company will ask the auditor to reschedule the audit assignment. Second, the auditor will be more careful during the audit process if it is believed that this loss may be due to the company's financial failure and fraudulent management of information about the company's earnings.

Listiana and Susilo (2010) Nelson and Shukeri (2011); Modugu (2012), Ariyani and Budiartha (2014); Darsono (2014); Carbaja and Yadnyana (201) Writers and Latrini (2016) Widhiyani (2016); Wulandari and Utama (2016) Fathi and Gerayli (2017); Gunarsa and Putri (2017); Mazkiyani and Handoyo (2017); Murti and Suparsada and Putri (2017); Kusuma (2018) state that profitability has a negative effect on audit report lag. This shows that companies that have high profitability tend to be faster in submitting financial reports. Increased profitability provides good news to stakeholders so that management tries to present financial reports more quickly. Companies that have a high level of profitability have a greater incentive to publish their performance by making financial reports in a timely manner to the public so that there is no audit report lag, therefore the following hypothesis can be drawn:

\section{H2: Profitability has a negative effect on the audit report lag}

Liquidity is the company's ability to meet its short-term obligations. When a company has high liquidity, the condition and the performance of the company to meet its short-term obligations is also good so the company will give a good signal by tending to deliver financial 
reports in a timely manner and that is a good news. Conversely, when a company has low liquidity, the company's performance to meet its short-term obligations is low so the company will give bad signals by tending to deliver financial reports inappropriately and that is a bad news. Researches by Suharli (2006), Khiyanda (2013), Gusti Ayu and Made Gede (2014) and Suci (2015) show that liquidity has a negative effect on audit report lag.

H3: Liquidity has a negative effect on the audit report lag

The opinion given by the auditor greatly influences the timeliness of financial reporting. When a company gets an unqualified opinion, they will provide a good signal by tending to be fast and accurate in reporting its finances because the company is in good condition and this is a good news. Conversely, if the company gets an unfair opinion, the company will give a bad signal by tending to be late in reporting its finances because it is a bad news. Researches by Soltani (2002), Turel (2010); Shukeria Nelson (2011); , Al Daoud (2014); Nela Fatmawati (2018) show that audit opinion has a negative effect on audit report lag

\section{H4: Audit opinion has a negative effect on the audit report lag}

According to Loeb (1971) in Hilmi and Ali (2008) states that large public accounting firms have accountants who behave more ethically than accountants in small public accounting firms. Thus, large accounting firms have a better reputation for auditing and providing public opinion. So that a public accounting firm that has a good reputation will give a good signal by tending to be on time in publishing its financial reports to avoid audit report lag. Conversely, a small accounting firm, with a bad reputation in conducting audit work and providing public opinion, will give a bad signal with the tendency not to be on time in the delivery of financial reports so it will cause an audit report lag. Researches by Wahyu Adhy (2010) and); Rina Yuniarti (2016), show that the reputation of public accounting firm has a negative effect on the audit report lag.

H5: The reputation of public accounting firm has a negative effect on the audit report lag.

The population used in this research is 20 companies in the infrastructure, utility, and transportation services sector that experienced audit report lag which are listed on the Indonesia Stock Exchange by observing financial statement data for 6 years from 2014-2019, so the total population is as much as 120 financial report data. The sample selection was carried out by using purposive sampling technique, namely selecting samples with certain criteria. These criteria are as follows:

a. Infrastructure, utility and transportation service sector companies that have experienced an audit report lag of more than 90 days in 2014-2019.

b. Infrastructure, utility, and transportation service sector companies that include the date of the auditor's report and have a closing date for December 31.

c. Infrastructure, utility, and transportation service sector companies that publish complete financial reports with auditors' reports in 2014-2019.

\section{Result and Discussion}

From the Table 1, it can be seen that for all variables it shows that $\mathrm{H} 0$ is rejected and $\mathrm{Ha}$ is accepted, this means partially the level of leverage, profitability, liquidity, audit opinion and public accounting firm's reputation have significant effect on the audit report lag. A complete explanation for the output of data processing results can be seen in table 1 . 
Table 1. T test results

\begin{tabular}{|c|c|c|c|c|}
\hline Variable & Coefficient & Std. Error & t-Statistic & Prob. \\
\hline $\mathrm{C}$ & 0.087408 & 1.377639 & 0.063448 & 0.9496 \\
\hline LEV? & 0.127319 & 0.058551 & 2.174522 & 0.0323 \\
\hline PROFIT? & -0.484996 & 0.234800 & -2.065571 & 0.0418 \\
\hline LIQUID? & -2.248096 & 0.270386 & -4.314408 & 0.0000 \\
\hline $\mathrm{AO} ?$ & -0.046577 & 0.024472 & -1.903260 & 0.0402 \\
\hline AFR? & -0.033855 & 0.011229 & -3.014884 & 0.0033 \\
\hline
\end{tabular}

The results of hypothesis 1 indicates that leverage has a positive effect on audit report lag. The significant test results prove that companies that fund their assets with debt are likely to be late in submitting their financial statements, on the other hand, if the debt owned by the company for the use of assets is low, it is likely that they will be on time to deliver the financial reports. An auditor can carry out his audit work quickly if his client company does not experience financial failure. This financial failure can be caused by several factors, including the level of liquidity, profitability, funding structure, industry profile, and management competence.

So it can affect the delay in audited financial reporting. Every company certainly needs funds to carry out its operational activities, so a management role is needed in making the right funding decisions for the company (Prabandari, 2010). Companies with a large scale tend to require more funds in carrying out their company's operational activities compared to smallscale companies. The funds needed by the company come from the company owner as well as loans from outsiders, so it will result in debt that must be paid by the company. Debt is one aspect that becomes the basis for investors to measure financial conditions. This financial condition can be measured using financial ratios, one of which is the leverage ratio. The high debt to equity ratio for large and small-scale companies will reflect the company's high financial risk. High corporate financial risk also shows that the company is experiencing financial distress as a result of high liabilities.

The results of hypothesis 2 indicates that there is a significant negative effect of profitability on companies with high levels of profitability or companies with high levels of income. They tend to be broader and faster in reporting financial reports each year, so the possibility of companies to report financial reports on time is higher, because it is a good news and also a good signal for stakeholders, especially investors. On the other hand, a company with a low level of profitability tends to be slow in reporting its finances because it is a bad news and a bad signal for stakeholders.

The third hypothesis in this study is to partially test the effect of the liquidity variable on the audit report lag. Based on the results, it shows that the liquidity variable has significant negative effect. The negative direction shown by the regression coefficient means that the higher the level of liquidity, the higher the probability of the company to report on time. The significant test results prove that companies that are able to meet their high short-term obligations are more punctual in submitting financial reports, and this shorten the audit report lag. These results support the researches of Khiyanda (2013), Ayu and Made (2014), Suci (2015) which state that liquidity has a positive effect on the timeliness of financial reporting. 
The fourth hypothesis in this study is to partially test the effect of the auditor's opinion variable on the audit report lag. Based on the results of the test, it shows that the auditor's opinion variable has a positive and significant effect. The negative direction shown by the regression coefficient implies that the better the opinion issued by the auditor, namely the unqualified opinion, the higher the possibility of the company reporting on time. The negative and significant test results indicate that the research results can be generalized to all members of the population. So this study accepts Ha which states that the auditor's opinion partially has a negative effect on the audit report lag. The significant test results prove that the company that gets unqualified opinion is likely to be on time in submitting the financial report because it is a good news and companies that get an opinion other than an unqualified opinion are likely to be late in submitting their financial statements because that is a bad news.). Companies that get an unqualified opinion will immediately publish their financial statements to show that they are feasible and has been well managed by investors. This supports the researches of Nela Fatmawati (2018), Al Doud (2014), Turel (2010) which show that auditor opinion has a negative effect on audit report lag.

The results of the fifth hypothesis indicate that there is a negative and significant effect. So this research accepts Ha which states that public accounting firm's (KAP) reputation partially and negatively affects the timeliness of financial reporting. Significant test results prove that public accounting firms that have good reputation or are affiliated with The Big Four of public accounting firm (KAP) will tend to be on time so the audit report lag will take shorter time in publishing its financial statements because it is a good news. Large public accounting firms have accountants who behave more ethically than small public accounting firms so large accounting firms have a better reputation for auditing and providing public opinion. Companies that have a good public accounting firm's reputation will immediately publish their financial reports to show that the company is feasible and has been properly managed by stakeholders. This supports the researches of Rina Yuniarti (2016), Wahyu Adhy (2010), Suharli (2006) which show that the reputation of public accounting firm has a negative effect on audit report lag.

\section{Conclusion}

Based on the results of research that has been carried out on companies in the infrastructure, utility, and transportation services sector that experienced an audit report lags listed on the Indonesia Stock Exchange in 2014-2019, the following conclusions are drawn:

a. Leverage has a significant positive effect on audit report lag. This means that when the variable leverage level increases, the audit report lag will increase, and vice versa, if the leverage level decreases, the audit report lag will decrease.

b. Profitability has a significant negative effect on audit report lag. That is, when the variable increases, the profitability audit report lag will fall or be reduced, and vice versa if the variable profitability goes down the audit report lag will rise or increase.

c. Liquidity has a significant negative effect on audit report lag. When the variable increases, the profitability audit report lag will fall or be reduced, and vice versa if the variable of profitability goes down the audit report lag will rise or increase.

d. Audit opinion has a significant negative effect on audit report lag. When the better audit opinion obtained in the previous year, it will shorten the audit report lag. 
e. The reputation of the public accounting firm has a significant negative effect on the audit report lag. This means that when a company chooses an accounting firm that is affiliated with the Big Four of public accounting firm, the audit report lag will be shorter.

\section{References}

[1] Ariyani, Ni Nyoman Trisna Dewi dan I Ketut Budiartha. 2014. Pengaruh Profitabilitas, Ukuran Perusahaan, Kompleksitas Operasi Perusahaan, dan Reputasi KAP terhadap Audit Report Lag pada Perusahaan Manufaktur. E-Jurnal Akuntansi Universitas Udayana 8.2 (2014), pp : 217-230.

[2] Carbaja, L. K. I. C dan Yadnyana, I. K. (2015). Pengaruh Profitabilitas, Ukuran Perusahaan, Reputasi KAP, dan Pergantian Auditor pada Ketidaktepatwaktuan Pelaporan Keuangan. EJurnal Akuntansi Universitas Udayana ISSN: 2302-8556 Vol. 13, No. 2: 615-624.

[3] Darsono, D. H. (2014). Faktor-Faktor Pemengaruh Audit Report Lag. Diponegoro Journal of Accounting ISSN 2337-2806 Vol. 3, No. 2: 1-9.

[4] Fathi, M. dan Gerayli, M. S. (2017). Firm Specific Characteristics and Audit Report Delay: Empirical Evidence from Iranian Firms. International Journal of Economic Perspective Vol. 11, No. 3: 1078-1083.

[5] Fadoli, Imam. 2014. Pengaruh Faktor Internal dan Eksternal Terhadap Audit Report Lag (Studi Empiris pada Perusahaan Manufaktur dan Perbankan yang Terdaftar di BEI tahun 2008-2013). Jurnal Bisnis Akuntansi : Badan Penerbit Univeritas Diponegoro,4 (2), pp: 35-67.

[6] F. R. Ibrahim, And Z. Zulaikha, "Audit Report Lag : Faktor - Faktor Pengaruh Dan Dampaknya Terhadap Respon Pasar Pada Saham Perusahaan Manufaktur Yang Beredar (Studi Empiris Pada Perusahaan Manufaktur Indonesia)," Diponegoro Journal Of Accounting, Vol. 8, No. 4, Nov. 2019

[7] Gunarsa, I G. A. C. dan Putri, I. A. D. (2017). Pengaruh Komite Audit, Independensi Komite Audit, dan Profitabilitas Terhadap Audit Report Lag di Perusahaan Manufaktur. E-jurnal Akuntansi Universitas Udayana ISSN: 2302-8556 Vol. 20, No. 2: 1672-1703.

[8] Hastutik, Suci. 2015. Pengaruh Profitabilitas, Likuiditas, Kepemilikan, Ukuran Perusahaan dan Opini Audit terhadap Ketepatan Waktu Pelaporan Keuangan Perusahaan. Jurnal Akuntansi dan Sistem Teknologi Informasi. Vol 11, 102-111.

[9] Hilmi, Utari dan Syaiful Ali. 2008. "Analisis Faktor-Faktor Yang Memepengaruhi Ketepatan Waktu Penyampaian Laporan Keuangan (Studi Empiris pada Perusahaan-perusahaan yang Terdaftar di BEJ)". Simposium Nasional Akuntansi XI Ikatan Akuntan Indonesia.

[10] IAI. 2017. Standar Akuntansi Keuangan. Jakarta : November 2017.

[11] I Gusti Ayu Ratih Permata Dewi.Made Gede Wirakusuma, Fenomena Ketepatwaktuan Informasi Keuangan Dan Faktor Yang Mempengaruhi Di Bursa Efek Indonesia Issn: 2302, 8556, Jurnal Akuntansi Universitas Udayana 8, 1 (2014): 171- 186।

[12] Indriyani dan Supriyati. 2012. "Faktor-Faktor Yang Mempengaruhi Audit Report Lag Perusahaan Manufaktur di Indonesia dan Malaysia". The indonesian Accounting Review, Volume 2, Nomer 2, STIE Perbanas Surabaya.

[13] Keputusan Ketua Badan Pengawas Pasar Modal dan Lembaga Keuangan Nomor: KEP346/BL/2011 tentang Penyampaian Laporan Keuangan. http://www.bapepam.go.id. Diakses tanggal 13 Oktober 2016.

[14] Keputusan Ketua Badan Pengawas Pasar Modal dan Lembaga Keuangan Nomor: Kep431/BL/2012 tentang Penyampaian Laporan Keuangan. http://www.bapepam.go.id. Diakses tanggal 13 Oktober 2016

[15] Kurniasih, Nia. 2016. Pengaruh Profitabilitas, Likuiditas, dan Ukuran Perusahaan terhadap Audit Report Lag (Studi Kasus pada Perusahaan Sektor Jasa Infrastruktur, Utilities, dan Transfortasi yang Mengalami Audit Report Lag yang Terdaftar di Bursa Efek Indonesia pada Periode Tahun 20072014). Skripsi Akuntansi 2016. 
[16] Kusuma, B. C. (2018). Ukuran Perusahaan Sebagai Variabel Moderasi Pengaruh Profitabilitas, Financial Distress, dan Kepemilikan Publik Terhadap Audit Report Lag. Skripsi. Program Studi Akuntansi Fakultas Ekonomi dan Bisnis Universitas Muhammadiyah Surakarta.

[17] Listiana, Lisa dan Susilo. 2012. Faktor-faktor Yang Mempengaruhi Reporting Lag Perusahaan. Media Riset Akuntansi. Vol. 2, No. 1 Universitas Bakrie.

[18] Mazkiyani, N. dan Handoyo, S. (2017). Audit Report Lag of Listed Companies in Indonesia Stock Exchange. Jurnal aplikasi bisnis p-ISSN: 1411-4054 / e-ISSN : 2579-3217 Vol. 17, No. 1: 77-95.

[19] Modugu, Prince Kennedy, Emmanuel Eragbhe, dan Ohiorenuan Jude Ikhatua. 2012. Determinan of Audit Delay in Nigerian Companies:Empirical Evidence. Research Journal of Finance and Accounting Volume 3 Nomor 6, 2012.

[20] Murti, N. M. D. A. dan Widhiyani, N. L. S. (2016). Pengaruh Ukuran Perusahaan dan Profitabilitas pada Audit Delay dengan Reputasi Kantor Akuntan Publik sebagai Variabel Pemoderasi. E-Jurnal Akuntansi Universitas Udayana ISSN: 2302-8556 Vol. 16, No. 1: 275-305.

[21] Ningsih, Catur Wulan. 2013. Faktor - faktor yang Mempengaruhi Audit Delay Studi Empiris pada Perussahaan Consumer Goods yang Terdaftar di BEI periode 2009-2012. Jurnal. Universitas Maritim Raja Ali Haji.

[22] Nelson, S. P. dan Shukeri, S. N. (2011). Corporate Governance and Audit Report Timeliness: Evidence from Malaysia. Research in Accounting in Emerging Economies ISSN: 1479- 3563 pages 109-127.

[23] Putri, Alvyra Nesia Indah. 2014. Faktor-Faktor yang Berpengaruh Terhadap Audit Report Lag pada Perusahaan Manufaktur yang Terdaftar di Bursa Efek Indonesia Periode Tahun 2008-2012. Skripsi Ekonomika dan Bisnis 2014.

[24] Sastrawan, I Putu dan Made Yeni Latrini. 2016. Pengaruh Profitabilitas, Solvabilitas, dan Ukuran Perusahaan Terhadap Audit Report Lag Pada Perusahaan Manufaktur. E-Jurnal Akuntansi Universitas Udayana. Vol.17, No.1

[25] Setiawan, Heru. 2013. Pengaruh Ukuran Perusahaan, Reputasi Auditor, Opini Auditor, Profitabilitas, dan Solvabilitas terhadap Audit Delay. Skripsi Akuntansi 2013.

[26] Suharli dan Rachpriliani. 2006, Studi Empiris Faktor-Faktor Yang Berpegaruh Terhadap Ketepatan Waktu Pelaporan Keuangan, Jurnal Bisnis dan Akuntansi, Vol 8 No. 1, April 2006.

[27] Wulandari, N. P. W., dan Utama, I. M. K. (2016). Reputasi Kantor Akuntan Publik Sebagai Pemoderasi Pengaruh Profitabilitas dan Solvabilitas pada Audit Delay. E-Jurnal Akuntansi Universitas Udayana ISSN: 2302-8556 pages 1455-1484.

[28] Zulaika, Ratna. 2016. Analisis Faktor Internal Perusahaan yang Mempengaruhi Audit Delay pada Perusahaan Pertambangan yang Terdaftar di BEI pada Tahun 2010-2014. Skripsi Akuntansi 2016 